\title{
REPORTING SCOTLAND IN THE ANGLO-SAXON CHRONICLE
}

\begin{abstract}
Alex Woolf
The aim of this paper is to explore the changing way in which the AngloSaxon Chronicle reports events in northern Britain, beyond the AngloSaxon territories, in the hope of gaining a better understanding both of events in that region and, perhaps more interestingly, the way in which the Chronicle was constructed. Since the Chronicle is principally a West Saxon text, produced at the southern end of the island, the transformation in its own perspective may reflect the changing horizons of the West Saxon learned elite. As in any such study of the Chronicle this exploration must begin with an examination of MS A, widely, if not universally, regarded as the closest witness we have to the chronicle's earliest, and most thoroughly West Saxon, form. ${ }^{1}$ For this initial analysis the interpolations of Hand 8, the principal scribe of MS F, will be ignored since these, for the most part, represent material derived from the Northern Recension of the Chronicle which I hope to discuss at a later occasion. ${ }^{2}$

The earliest 'Scottish' reference found in MS A is the mention of the Emperor Claudius's conquest of Orkney at $46 \mathrm{~A}$ which was probably derived from Bede who had obtained the erroneous date of AD 46 from Eutropius. ${ }^{3}$ The point of the allusion here, as in the texts from which it derives, seems simply to have been to emphasize the completeness of Roman hegemony in Britain rather than to reflect any real interest in the far north. A more fruitful and systematic analysis can be

\footnotetext{
${ }^{1}$ Bately, $M S A$.

${ }^{2}$ Bately, $M S A$, p. xl.

${ }^{3}$ Bede, HE, I, 3 and V, 24. Eutropius, Breviarum ab urbe condita, VII, 13, 3, ed. by H. Droysen,
} MGH AA, 2 (Berlin, 1879).
\end{abstract}


pursued with regard to the ethnonyms applied to northern peoples: Cumbere, Peohtas, Stracledwalas, and Scottas.

Of these peoples the first mentioned are the $S$ cottas, who appear in entries for the years $430,565,597,891,902,920,937,945$, and 946 . The first of these entries for 430A ('Her Paladius se biscep wæs onsended to Scottum pæt he hiera geleafan trymede from Cęlestino pam papan') again derives from Bede. ${ }^{4}$ Ultimately Bede's information came from Prosper of Aquitaine who clearly intended the Irish as the recipients of Palladius's ministry. The entry for 565, recording the mission of Columba, is likewise derived from Bede. ${ }^{5}$ The entry for $597 \mathrm{~A}$ is, on the other hand, particularly curious. It reads:

Her ongon Ceolwulf ricsian on Wesseaxum 7 simle he feaht 7 won, oppe wip Angelcyn, oppe uuip Walas, oppe wip Peohtas, oppe wip Scottas. ${ }^{6}$

Historians have been sceptical of the claims made for Ceolwulfs pan-British activities, and it would seem rather to reflect the concerns of a later age when West Saxon rulers did indeed have such wide ambitions. This entry marks the final reference to $S$ cottas before the 890 s which, whatever date one wishes to postulate for the inception of the Chronicle, was certainly within the lifetime of the originator(s) of the project. ${ }^{7}$ The entry for 597 differs from those for 430 and 565 in a number of ways. Firstly, it is not derived from Bede, who does not mention this king, nor is it concerned with ecclesiastical matters. It is also noteworthy that the accounts of Palladius and Columba use to Scottum and of Scottum to denote movement to and from Ireland whereas the most likely interpretation of the account of Ceolwulf s wars is that he was in conflict with the peoples of Britain. It is tempting to link this catalogue of opponents with Bede's account of the populating of Britain in $H E, \mathrm{I}, 1$. Here Bede lists the secular languages of Britain as English, British, Gaelic (Scottorum), and Pictish (in that order) and then goes swiftly on to tell of the coming of the Britons, the Picts, and the Scots (in that order) to the island. The order of the list of Ceolwulfs foes matches that in the summary of origin legends (though the English are absent from Bede's account) rather than that of the list of languages. While it is tempting to view the claims made here for Ceolwulf as a

\footnotetext{
4 'Here Palladius the bishop was sent to the Scots, that he may strengthen their faith, by Pope Celestine', following Bede, $H E, \mathrm{~V}, 24$.

${ }^{5}$ Bede, $H E, \mathrm{~V}, 24$.

${ }^{6}$ Bately, $M S A$, 597. 'Here Ceolwulf began to rule among the West Saxons and continuously he fought and contended either with Angelcyn, or with Wealas or with Peohtas or with Scottas.'

${ }^{7}$ For the debate, see other contributions to this volume and Dumville, 'Origins'.
} 
product of Alfredian propaganda, it is worth noting that Alfred and his kindred did not themselves claim descent from Ceolwulf. ${ }^{8}$ Ceolwulf was, however, the last king of the West Saxons to die a pagan, and this may have been of some significance. We are, after all, not told that Ceolwulf won his battles, and it may be that the message which we were intended to receive was that every man's hand was turned against him. While it is perfectly possible that a sixth-century West Saxon king might have fought against Scottas, either the descendants of Irish settlers in Dyfed or those in Devon and Cornwall, or genuine raiders from Ireland, it seems unlikely that he would have numbered Peobtas among his enemies. In summary it seems most likely that this represents a retrospective exercise of some kind produced by the author of the first recension of the Chronicle.

What all three of these entries have in common is that they belong to the protohistoric phase of the Chronicle for which it is unlikely that any native English written records were available to the chronicler. The absence of any references to Scottas from the pre-Alfredian Christian era, on the other hand, almost certainly reflects the myopic vision of the chroniclers whose annals underlie the surviving text of the Chronicle from the seventh to the ninth centuries and to some extent their selective use of Bede.' The entries in MS A concerning Palladius and Columba seem to be drawn from the annalistic epitome with which Bede concluded his Historia Ecclesiastica, and indeed are two of the only three entries to mention Scotti in that work:

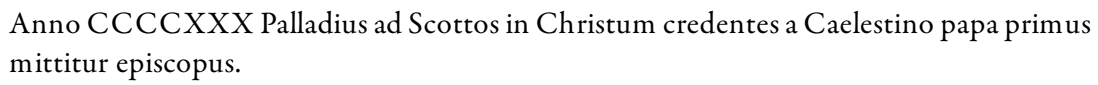

${ }^{9}$ For which see Janet M. Bately, 'The Compilation of the Anglo-Saxon Chronicle 60 BC to AD 890: Vocabulary as Evidence', $P B A, 64$ (1978), 93-129; and Bately, 'World History in the AngloSaxon Chronicle: Its Sources and its Separateness from the Old English Orosius', ASE, 8 (1979), 177-94.

${ }^{10}$ Bede, HE, V, 24. '430. Palladius was sent by Pope Celestinus to be the first bishop of the Irish Christians.' '565. The priest Columba came from Ireland to Britain to teach the Picts and established the monastery on Iona.' '664. There was an eclipse. King Eorcenberht of Kent died and Colmán and his Irish returned to their own people.' 
The final and third notice here, that of Colmán's return to Ireland after the Synod of Whitby, also made it in to the A-text of the Chronicle but, perhaps purely for stylistic reasons, the Scott- word was not used:

AN dclxiiii Her sunne apiestrode, 7 Arcenbryht Cantwara cyng forpferde; Colman mid his geferum for to his cyððe. ${ }^{11}$

In this entry it is unambiguously the case that $H E, \mathrm{~V}, 24$ was the source for the annal.

The pattern for the Peohtas is very similar. They appear s.a. 565, 597,710, and 875. The entries for 565 and 597, concerning Columba and Ceolwulf respectively, we have already dealt with. That for 710 is an interpolation by Hand 3, a scribe of the mid-tenth century, but since the entry also appears in MS C it is deemed likely that it was part of the original set of annals for this period and was omitted through carelessness by the scribe who copied the entries to AD 891 in MS A. ${ }^{12}$ It is also drawn from Bede's chronological summary at the end of Historia Ecclesiastica. ${ }^{13}$

The entry for 875 represents what might be termed the (near-)contemporary phase of the first recension. This entry, $875 \mathrm{~A}$, also marks the first appearance of the Stracledwalas who also appear in 920A. 875A is a lengthy entry on the doings of the Great Army:

Her for se here from Hreopedune, 7 Healfdene for mid sumum pam here on Norphymbre

7 nam wintersetl be Tinan pære ei, 7 se here pæt lond geode 7 'o'ft hergade on Peohtas 7 on Stręcledwalas. ${ }^{14}$

This passage also appears, translated into Latin, in $\$ 47$ of Asser’s Life of King Alfred, thus confirming its existence by the 890 s. As a final reference to the Picts in contemporary English sources, and as the only genuinely contemporary reference to them in the Chronicle, it coincides neatly with the Irish chronicle tradition which uses the description rex Pictorum for the last time in the obit of Aed son of Cinaed in $878 .{ }^{15}$ By the late eleventh century, at the latest, Irish synthetic

\footnotetext{
11 'Here the sun was eclipsed and Eorcenberht king of the Cantware passed away; Colmán with his companions went to his own homeland.'

${ }^{12}$ Bately, MS A, pp. xxxiv-xxxv; Dumville, 'Origins', p. 66. This instance provides the clearest evidence that MS A was not the 'original' of the Chronicle as has sometimes been supposed.

${ }^{13}$ Bede, $H E, \mathrm{~V}, 24$, s.a. 711.

${ }^{14}$ Bately, MS A, 875A. 'Here the army went from Repton and Healfdene went with some of that army among the Northumbrians and took winter quarters by the river Tyne there, and the army conquered that land and often harried among the Peobtas and among the Strecledwalas.'

15 The Annals of Ulster (to AD 1131), ed. by S. Mac Airt and G. Mac Niocaill (Dublin, 1983) (henceforth $A U$ ), s.a. 878.2. Chronicum Scotorum, ed. by W. M. Hennessy (London, 1866), does
} 
historians reckoned that Aed's brother and predecessor Constantín, who had died in 876 , had been the last king of the Picts. ${ }^{16}$

The coincidence of terminology between the Irish chronicles and the AngloSaxon Chronicle in this period is not confined to the case of the Picts. $A U 872.5$ notices the killing of Artgal rex Britanorum Sratha Cluade, the first use of the Irish term cognate to Stracledwalas in the chronicle record. Prior to this there had been notice of kings of Ail Cluaithe, 'Clyde Rock' at Dumbarton, but not of Sratha Cluaide. Although the form is British in origin, Ystrad Clud in Modern Welsh orthography, meaning 'Clydesdale', it appears only once in the A-text of the Annales Cambriae s.a. 945. ${ }^{17}$ Thus the first Chronicle notice of this people coincides with a changing Irish perception of the political geography of the area. It cannot be emphasized enough, however, that the appearance of the north in a West Saxon text at this point is largely due to the interest of the chronicler in the movements of the Great Army. It was the broad horizons of Healfdene and his kinsmen, mare mearcstapas that they were, which drew the gaze of southron eyes upon the Peohtas and Stracledwalas. Nonetheless the contemporary nature of MS A for the late ninth and early tenth centuries also allows us to view its use of Scottas from a new perspective. The entries for 891 and probably 902 are concerned with Irish ecclesiastics, in the former case with the three wanderings scholars who arrived at Alfred's court, and in the latter with the obit of an unidentified Uirgilius abbud of Scottum. ${ }^{18}$ There seems to be no corresponding obit for a 'Virgil' in the Irish chronicles, and thus it is quite likely that he was an expatriate Gael, perhaps one of those scholars like Asser and John the Old Saxon who had come to serve in Alfred's kingdom.

The annal for 920 is the last entry in quire $\mathrm{C}$ and the last entry in the hands labelled $2 \mathrm{a}-\mathrm{f}$ written by one or more scribes between $c .915$ and the later $920 \mathrm{~s}^{19}$ This entry marks the end of the account of Edward the Elder's campaigns which is unique to MS A. This account may well have been written at Winchester. The

not note Aed's death and thus the obit of his brother Constantín, s.a. 876 (also noticed in $A U$ ), is its final instance of rex Pictorum.

${ }^{16}$ M. O. Anderson, Kings and Kingship in Early Scotland (Edinburgh, 1973), pp. 78-79. Aed's very short reign, noticed only in this obit, may have been easily forgotten. Even his obit is missing from the Clonmacnoise group of chronicles.

${ }^{17}$ Annales Cambriae, AD 682-954: Texts A-C in Parallel, ed. by David Dumville, Basic Texts for Brittonic History, 1 (Cambridge, 2002), p. 16.

${ }^{18} 891 \mathrm{~A}$ and 902A. See also David N. Dumville, Three Men in a Boat: Scribe, Language and Culture in the Church of Viking-Age Europe (Cambridge, 1997).

${ }^{19}$ Dumville, 'Origins', pp. 55-98, and Bately, $M S A$, pp. xxv-xxxiv. 
annal for 920 tells of Edward's securing of the north-central frontier of Mercia through the construction of burhs at Nottingham and Bakewell and of a bridge at Nottingham linking his own burh to that built by the Great Army on an earlier occasion. The entry continues:

7 hine geces pa to fæder 7 to hlaforde Scotta cyning 7 eall Scotta peod, 7 Rægnald 7 Eadulfes suna 7 ealle pa pe on Norphymbrum bugeap, ægper ge Englisce ge Denisce ge Norpmen ge opre, 7 eac Stræcledweala cyning ealle Stræcledwealas. ${ }^{20}$

This episode is clearly the sequel to a northern event not noted in the A-text nor even in the Northern Recension of the chronicle: the Battle of Corbridge. Accounts of this battle are, however, preserved in the Annals of Ulster, in the Scottish chronicle known now as the Chronicle of the Kings of Alba, and in Historia de Sancto Cuthberto.

AU 918.4 The Gaill of Loch Dá Cháech, i.e. Ragnall, king of the Dark Gaill, and the two earls Oitir and Gragabai, forsook Ireland and proceeded afterwards against the men of Alba. The men of Alba, moreover, moved against them and they met on the banks of the Tyne in northern 'Saxony'. The heathens formed themselves into four battalions: a battalion with Gothfrith grandson of Ímar, a battalion with the two earls, and a battalion with the 'young lords' (Gaelic óctigerna). There was also a battalion in ambush with Ragnall which the men of Alba did not see. The men of Alba routed the three battalions which they saw, and made a very great slaughter of the heathens, including Oitir and Gragabai. Ragnall, however, then attacked in the rear of the men of Alba, and made a slaughter of them, although they did not lose a king or mormaer. Nightfall caused the battle to be broken off. ${ }^{21}$

Historia de Sancto Cutbberto recounts the story thus:

These he performed faithfully until King Rægnald came with a great multitude of ships and occupied the territory of Ealdred son of Eadwulf, who was a friend of King Edward, just as his father Eadwulf had been a favourite of King Alfred. Ealdred, having been driven off, went therefore to Scotia, seeking aid from King Constantín, and brought him into battle against Rægnald at Corbridge. In this battle, I know not what sin being the cause, the pagan king vanquished Constantín, routed the Scots, put Elfred the faithful man of St Cuthbert to flight and killed all the English nobles save Ealdred and his brother Uhtred. ${ }^{22}$

${ }^{20}$ Bately, $M S A, 920$ A. 'And then he was chosen as father and lord by $S$ cotta king and the $S$ cotta nation and by Rægnald and by the sons of Eadwulf and all those who dwelt in Northumbria whether English, or Danish or Norsemen, or other, and also by the Stracledweala king and all the Stracledwealas.'

${ }^{21} A U, 918.4$.

${ }^{22}$ Historia de Sancto Cuthberto, ed. by Ted Johnson South, Anglo-Saxon Texts, 3 (Cambridge, 2002), \$22. For the much briefer notice in the Chronicle of the Kings of Alba, see B. T. Hudson, 'The Scottish Chronicle', Scottish Historical Review, 77 (1998), 129-61. 
From these accounts we can infer that Rægnald, a Viking leader active in Ireland, had contested control of Northumbria with its native rulers, Ealdred and Uhtred sons of Eadwulf; that the latter had called upon Constantín king of Alba to help them; and that, Rægnald having held the field, after a somewhat pyrrhic victory, Edward stepped in as a peace broker; Northumbria's adversity was Edward's opportunity. ${ }^{23}$ If this interpretation is correct and the unnamed Scotta cyning of $920 \mathrm{~A}$ is indeed Constantín of Alba then this is the first near contemporary use of the Scott-term for the northern kingdom. Constantín himself appears to have been the son of that Aed who was the last rex Pictorum noted in the Irish chronicles, or so a late tenth-century pedigree would have us believe. ${ }^{24}$ From the perspective of the Anglo-Saxon Chronicle, then, we can perhaps say that Pictland had been transformed into Scotland at some point between 875 and the mid- to late 920s when the entry concerning Edward's meeting with the northerners was written. It is much to be regretted that interest in the North waned in Wessex between the death of Healfdene and the 920s.

Just as 920A marks the first appearance of Albanian Scottas in the Anglo-Saxon Chronicle so it also marks the final appearance of Stracledwealas, previously encountered alongside the Peohtas in 875A. The absence of the Stracledwealas from the accounts of the Battle of Corbridge may incline us to note with caution the use of eac to introduce the Stracledweals cyning in 920A. Is the chronicler here signalling that the submission of the Strecledwealas was separate from Edward's negotiations with the rulers who had fought at Corbridge?

With the annal for 920 we come to the end of the near-contemporary initial phases of MS A and, to some extent, this version of the chronicle now loses its privileged position. The next section of the Chronicle, comprising fols $26^{\mathrm{r}}-27^{\mathrm{v}}$, was written, for the most part, by Hand 3 working in the mid-950s..$^{25}$ It may thus represent a retrospective account of the reigns of the sons of Edward. It is, nonetheless, clear from its relationship with the same sequence of annals in other versions of the Chronicle that whatever their provenance they do not originate with the scribe of Hand 3 but were copied from a pre-existing source. ${ }^{26}$ This 'Chronicle of

\footnotetext{
${ }^{23}$ For a review of the historiography of this notice of Edward's relations with the northerners, see Michael R. Davidson, 'The (Non)submission of the Northern Kings in 920', in Higham and Hill, pp 200-11.

${ }^{24}$ This pedigree is printed in full in its original form by John Bannerman in Studies in the History of Dál Riata (Edinburgh, 1974), pp. 65-66.

${ }^{25}$ Bately, $M S A$, pp. xxxiv-xxxv.

${ }^{26}$ An alternative possibility is that the scribe of Hand 3 simply updated MS A by copying entries from a version of the chronicle which had continued the Common Stock (Dumville,
} 
the Sons of Edward' mentions Scottas on three occasions, s.a. 937, 945, and 946, and also contains the earliest reference to the kingdom of Alba as Scotland, at 933A. As is well known the entry s.a. 937 is, in fact, the Brunanburh poem and clearly had an original existence independent of the Chronicle, as indicated by the fact that the poet writes Sceotta rather than Scotta. Nonetheless in the poem it is probable that the term is applied to Constantín's followers although it is by no means impossible that Irish followers of Anlaf might have been intended. The entries for 945 and 946, however, are clearly part of the main chronicle and are linked in that they serve to mark the high points of Eadmund's and Eadred's reigns:

Her Eadmund cyning oferhergode eal Cumbra land 7 hit let to eal Malculme Scotta cyninge on pæt gerad pæt he wære his midwyrhta ægper ge on sæ ge on lande.

7 pa feng Eadred æpeling his bropor to rice 7 gerad eal Norphymbra land him to gewealdan, 7 Scottas him apas sealdan, pæt hie woldan eal pæt he wolde. ${ }^{27}$

The first notice is clearly to Mael Coluim mac Domnaill king of Alba, and it would be perverse, albeit not impossible, to argue that the second notice did not also refer to the Albanians. 945A also contains the only reference to Cumbere in MS A. That the Cumbere were indeed the same people as those referred to as Strecledwealas is confirmed by the entry in the near contemporary A-text of Annales Cambriae: 'Et Strat Clut uastata est a Saxonibus. ${ }^{28}$ The reference to Scotland in this 'Chronicle of the Sons of Edward' unambiguously refers to northern Britain:

Her for Æpelstan cyning in on Scotland, ægper ge mid landhere ge mid scyphere, 7 his micel oferhergade. ${ }^{29}$

'Origins', p. 66). The absence of coverage between 920 and 924 and the extremely parsimonious coverage of Æthelstan's reign would seem to make this unlikely. More likely, perhaps, is that Hand 3 derived his source material from a copy of the Chronicle containing the Mercian Register but chose not to include it since Hand 2 had already provided annals for the bulk of the period which it covered.

${ }^{27}$ Bately, MS A, 945A: 'Here King Eadmund harried across all of the land of the Cumbere and let it all to Mael Coluim Scotta cyning on condition that he be his co-worker both on sea and on land.' Bately, $M S A$, 946A: 'And then Eadred Ætheling, his brother, took power and compelled all the land of the Northumbrians to accept his rule and the Scottas gave him oaths that they would do all that he wished.'

${ }^{28}$ Annales Cambriae, ed. by Dumville, 945A. '[A]nd Ystrad Clud (Strathclyde) was ravaged by the English.'

${ }^{29}$ Bately, $M S A$, 933A 'Here King Æthelstan went into Scotland, both with land-army and with fleet and he ravaged greatly.' 
It would have been very difficult for Æthelstan to have invaded Ireland ge mid landhere ge mid scyphere, yet as recently as the reign of his grandfather Alfred the anonymous translator of Orosius was able to write of 'Igbernia ðæt we Scotland hatap. ${ }^{30}$

There is perhaps some irony in the coincidence that the scribe who produced the earliest surviving copy of the Old English Orosius also provided Hand 2 of MS A, in which, s.a. 914, he wrote the earliest extant example of the word Irlande for Ireland. It seems probable that the scribe copied Orosius prior to $914 \mathrm{~A}$, and it is therefore interesting that he did not feel the need to correct either form but found both Scotland and Irland as acceptable names for the same place. ${ }^{31}$ Dumville has suggested that Irland represents a borrowing from Old Norse, but this not the only explanation possible. ${ }^{32}$ The Old English form might, rather, derive from British forms ancestral to modern Welsh Iwerddon (i.e. * Iwerijo) but only if they were borrowed early. Professor Jackson showed that in early borrowings of the iw+ following vowel' cluster from British into English the /w/ was lost and the rare, non-diphthong, i+e vowel cluster in Old English regularly contracts to i or $y .{ }^{33}$ The possibility exists that both usages coexisted within Old English or that they represent dialect variation (a point to which we shall return below).

So far as the other southern versions of the Chronicle are concerned our analysis of MS A, to this point, will also serve, noting of course the occasional variation in the calendar dates applied to individual annals. MS C does contain further references in the eleventh-century section of the chronicle, but northern affairs are notably absent from the late tenth-century sections of the southern versions of the Chronicle. ${ }^{34}$ Indeed, Scottas only appear again in the account of the reign of Edward the Confessor and its immediate aftermath at 1054, 1065, and 1066. Cumerland appears s.a. 1000, once again only to be harried.

${ }^{30}$ The Old English Orosius, ed. by Janet Bately, EETS, SS, 6 (London, 1980), I, 1, discussed in David N. Dumville, 'Ireland and Britain in Táin Bó Fraích', Études Celtique, 32 (1996), 175-87 (p. 181, n. 31).

${ }^{31}$ Dumville, 'Origins', p. 68.

${ }^{32}$ Dumville, 'Ireland and Britain', p. 181 and n. 33. Dumville also claims here that Yrlande in $891 \mathrm{~F}$ may be a contem porary annal, but in all other versions of the Chronicle 'Hibernia' is used at this point.

${ }^{33}$ Kenneth H. Jackson, Language and History in Early Britain (Edinburgh, 1953; repr. Dublin, 1994), pp. 374-75.

${ }^{34}$ O'Brien O'Keeffe, MS C. The so-called Mercian Register contains no references to northerners. 


\section{Discussion of the Southern Recension}

A simple listing of entries related in some way or other to Scotland is not in itself a particularly useful or enlightening exercise. Observations can be made, however, that shed more light on early Insular history, and in particular on the writing of the Chronicle. We have already noted, for example, the disappearance of the Peohtas between 875 and 920 which, in itself, is connected to the apparent relocation of the Scottas from Ireland to northern Britain between 891 and 920, and there are others areas which may prove far more illuminating.

Perhaps the most fruitful line of enquiry that remains concerns the transformation of the Strecledwalas into Cumere/Cumbere between 920 and 945. In terms of MS A this would seem to be a reflex of the switch from Scribe 2, whose work ended with 920A, to Scribe 3 who copied pre-existing annals for 924 to 946 into the manuscript retrospectively, c. 950 , and then continued a more-or-less contemporary record. The first occurrence of Cumbra land, at 945A, was presumably in Scribe 3's exemplar. This exemplar, Dumville has argued, comprised two principal elements:

a) a set of four local Winchester annals for 932-35; and

b) an account of royal successions and wars against the Northumbrians - 924, 934, $938-46 . .^{35}$

As Dumville points out, ' $[\mathrm{t}]$ he latter are found, generally in better textual condition, in other versions of the Chronicle $[s i c]$, but the former are unique to A'. It might therefore be argued that a better title for the Common Stock of the Chronicle in this period than the 'Chronicle of the Sons of Edward', proposed above, might be the 'History of the Conquest of Northumbria'. This being the case it may be that Cumbere represents a northern, perhaps Northumbrian, usage. This should, perhaps, hardly surprise us since until recently Cumberland, and now Cumbria, still figure(d) as administrative units of northern England. Symeon of Durham uses the Latin form Cumbrorum when discussing 'Owino', king of the Cumbrians in his Libellus. ${ }^{36}$ Historia Regum Anglorum also uses the term. ${ }^{37}$ The

\footnotetext{
${ }^{35}$ Dumville, 'Origins', p. 64.

${ }^{36}$ Symeon of Durham: Libellus de Exordio atque Procursu istius hoc est Dunhelmensis Ecclesie, ed. by David W. Rollason (Oxford, 2000), II, 18.

${ }^{37}$ Symeonis Monachi Opera Omnia, vol. II: Historia Regum, ed. by Thomas Arnold (London, 1885), p. 93 (Pt. I, s.a. 937), and in a number of other places deriving from Florence of Worcester or other post-Conquest sources. Anglo-Latin writers from before the Viking Age used terms such as Brettones and Britanni, etc., and did not attempt to Latinize either Walas or Cumbere.
} 
word itself can be derived, unproblematically, from the native term which lies behind modern Welsh Cymry (Welsh people, sg. Cymro) and Cymru ('Wales'). The modern distinction between these two terms, for people and land, had not yet arisen in the period with which we are concerned. Ultimately these terms derive from British *Combrogī, which seems to denote 'autochthons ${ }^{*}{ }^{38}$ Thomas CharlesEdwards has suggested that the development of the population group term was secondary and that it is a back formation from ${ }^{*}$ Combrogícā, meaning 'vernacular', coined to distinguish British Celtic from Latin. ${ }^{39}$ If, within English, the adoption of this term reflects northern usage two possibilities suggest themselves as explanations.

Firstly, as the inhabitants of the only British kingdom in the north the Stracledwalas may have felt that it was possible to appropriate the ethno-linguistic term to refer to their specific political grouping. In other words the Cumbrians may have called themselves Cumbrians. Writers in Wales, or familiar with Welsh, may have felt uncomfortable adopting such usage themselves since it would, inevitably, acquire an element of ambiguity in contexts where more than one kingdom of Cymry were involved. Amongst the Welsh, who seem to have been very comfortable with a 'British' ethnic identity which transcended individual kingdoms, polities tended to be named geographically. Although some of these geographical names may have evolved from ethnonyms, this does not seem to have been something of which the medieval Welsh were generally aware; thus, for example, although the name Gwynedd probably derives from an earlier *Wenedī (a population group name) a new population group name Wenedoti was developed to indicate 'People of Gwynedd'. The Annales Cambriae regularly uses territorial units rather than populations as its terms of reference. ${ }^{40}$ If it were the case that the rulers of the Clyde styled themselves kings of the Cymry then northern English writers may simply have adopted the Latin term current among the Stracledwalas to describe them.

The second possibility is that there had been, for quite some time, a genuine distinction in Old English usage between Cumbere/Cumere on the one hand and Wealas/Walas on the other. As noted above, in British, *Combrogi probably

${ }^{38}$ Geiriadur Prifysgol Cymru (Aberystwyth, 1950-2002), s.v. Cymro. The apparent absence of an equivalent term in Breton may reflect the view held by the Bretons that they were not autoch thonous to Armorica. Had the term existed it might, paradoxically, have been applied to the Gallo-Roman population.

39 Thomas Charles-Edwards, 'Language and Society among the Insular Celts AD 400 to 1000 ', in The Celtic World, ed. by M. Green (London, 1995), pp. 703-36.

${ }^{40}$ Annales Cambriae, ed. by Dumville, throughout. 
originally functioned to distinguish vernacular Celtic speakers from Romans. The English word Wealas seems, on the other hand, to have originally denoted 'Romans'. In MS A alone we have Galwalum at 650A and 660A, meaning 'among the Gallo-Romans', and Bretwalas (vel sim.) at 443A, 449A, 552A, 571 A, 682A, and $755 \mathrm{~A}$, which presupposes other kinds of wealh. MS E has Edward the Confessor return from exile in Wealland, 'France', which is regularly Valland in Old Norse and Walho-lant in Old High German. ${ }^{41}$ Weala sunderibt was used to gloss jus Quiritum. ${ }^{42}$ The popular explanation that wealh simply denoted 'foreigner' holds no water since it is always used of peoples who had at one time been within the Roman Empire and never of Gaels, Picts, Finns, Slavs, or other more exotic peoples. The word was even borrowed into Slavonic as Vlak/Vlach, 'a Rumanian', and Vlahu, Old Church Slavonic for 'Italy'. One might also consider the modern usage of Walloon in Flemish, for a French speaker, and Valais for the Italian-speaking region of Switzerland. One could go on. In the present context one might consider whether the early Anglo-Saxons had perhaps been able to distinguish between the RomanoBritish population they encountered in the south, to whom they may have applied the term wealas, and a more barbaric, less Romanized population in the north for whom they adopted the native word Cumbere. ${ }^{43}$ Further study of the distribution of both terms, in Old English texts and in place-names, may throw more light on this problem, but such study lies beyond the scope of the present paper.

Whichever of these hypotheses is correct, if the appearance of Cumbere in the Chronicle indicates northern influence on its vocabulary we might now consider two points; firstly, whether there are any other 'Northumbrianisms' which might be relevant to our discussion, and secondly, what might have informed the vocabulary regarding the north in the section of the text up to, and including, the annal for 920 .

In the former category the one item which suggests itself is Scotland. It seems likely that the Northumbrians, of all the Anglo-Saxons, will have been those who would have most regularly needed to distinguish between Ireland and the

\footnotetext{
${ }^{41}$ Irvine, MS E, and Bosworth Toller, s.v. Wealh-land.

${ }^{42}$ Bosworth Toller, s.v. Wealh. Romwealas also appears from time to time.

43 Cf. the arguments made by the present writer that the importance of the Old North in medieval Welsh literature stems from the fact that vernacular forms of literature and 'barbarian' patterns of kingship developed earlier there than in Wales itself; Alex Woolf, 'The Britons: From Romans to Barbarians', in Regna and Gentes: The Relationship between Late Antique and Early Medieval Peoples and Kingdoms in the Transformation of the Roman World, ed. by H.-W. Goetz, J. Jarnut, and W. Pohl with S. Kaschke (Leiden, 2002), pp. 345-81 (pp. 373-79).
} 
settlements of the Scottas in northern Britain. Is there any evidence of this? In $H E$, III, 5 Bede has Oswald ask for a bishop de prouincia Scottorum. Since the two bishops sent came from Iona, and Bede elsewhere uses Scotia to denote Ireland, and uses prouinicia in respect of that island only when subdividing it, it may be that his unproblematic use of prouincia Scottorum, implicitly inclusive of Iona, in $H E$, III, 5 reflects a vernacular Scotland, the province of the Scottas in Britain. Elsewhere Bede uses provincia for the territories of major Anglo-Saxon polities where the corresponding vernacular term was almost certainly land.

Support for the view that Scotland was an established name for Dál Riata may perhaps be found in Old Norse usage. Orkneyinga saga and Heimskringla both mention, on several occasions, an inlet of the sea called Skotlandsfjördr. ${ }^{44}$ Whilst most references are geographically vague and cannot be located more securely than to the west coast of Scotland, indeed there is some confusion as to whether the term is plural, -firdir, or singular,-fjördr; one reference in Chapter 41 of Orkneyinga saga gives a more specific description:

Magnús konungr helt paðan í Suðreyjar, en sendi menn sína í Skotlandsfjörðu; lét pá róa með öðru landi ut, en öðru inn ok eignar sér svá allar eyjar fyrir vestan Skotland. ${ }^{45}$

Magnus's fleet, we are told, rowed in and out of Skotlandsfjörðr, keeping the land to starboard. Their starting point was the western side of the narrow isthmus which divides Kintyre from Knapdale, now West Loch Tarbert. It is fairly clear then that Skotlandsfjöror was imagined to be the Atlantic end of the fault line that created the Great Glen and must have comprised the stretches of water now known as the Firth of Lorn and Loch Linnhe, the islands in question being those that lie between Kintyre and Ardnamurchan Point. Now from the perspective of the period of saga composition, the twelfth and thirteenth centuries, the Firth of Lorn was not the most obviously Scottish of fjords. Scottish royal power barely extended to the west coast, where reguli ruled in Argyll, and if the name 'Scotland's Fjord' were to be coined in this period then the Firth of Tay, leading to the important commercial, royal, and religious centres of Perth, Scone, and Dunkeld,

\footnotetext{
${ }^{44}$ Orkneyinga saga, ed. by Finnbogi Guðmundsson (Reykjavík, 1965), pp. 58, 99, 178, 274, and 387. Heimskringla, ed. by Bjarni Aðalbjarnarson, 3 vols (Reykjavík, 1951), III, 219 and 224. There are no references to Skotlandsfjördr/-firðir in the other volumes of Heimskringla or in the earlier collections of kings' sagas, and the contexts of the references here suggest that a version of Orkneyinga saga may, ultimately, have been Snorri's source.

45 Orkneyinga saga, ed. by Finnbogi Guðmundsson, p. 99. 'King Magnus steered thence into the Sudreyjar but he sent his men into Skotlandsfjördr ordering that they row both in and out with the land to starboard and thus he possessed himself of all the islands lying west of Scotland.'
} 
or the Firth of Forth, known in French, apparently, as Scottewatre because it separated 'Scotia proper' from the culturally Northumbrian province of Lothian, would both be more likely candidates. ${ }^{46}$

The most appropriate period for the name Skotlandsfjörðr to have been applied to a west coast feature would have been before the Scottish kingdom became securely located on the eastern coast and when Argyll formed the British portion of Dál Riata and was inhabited by those whom Bede described as 'Scotti qui Brittaniam incolunt'. ${ }^{37}$ Indeed the division of mainland and islands, described in the saga as having occurred in the time of Magnús bærfœtr, looks more like an account of a division of Dál Riata in the ninth century than an origin story for Norwegian hegemony over the Kingdom of the Isles in the eleventh or twelfth. The name Skotlandsfjörðr can be compared with that of Péttlandsfjördr which survives today as the Pentland Firth, separating Orkney from Caithness. The first element of this name, Péttland, means the 'Land of the Picts', Péttar being the Old Norse name for this people. ${ }^{48}$ The phonology of Péttar unambiguously betrays the fact that it originated as a loan word from Old English Peht or Peoht. The disappearance of the Picts from northern Britain at some point in the ninth or tenth centuries makes it fairly clear that the name of the 'firth' was coined during the Viking Age when the Picts were the southern neighbours of the Orcadians. ${ }^{49}$ If, like Péttland, Skotland was an English loan into Norse, and none of the other Insular vernaculars commonly used words deriving from Scotus, then it seems likely that Scotland was already in use in Old English, as a term for Argyll, before the end of the ninth century. Within Old English, however, such a usage may have been confined to Northumbria for West Saxons will have, most naturally, thought of Ireland as the land of the Scottas. ${ }^{50}$

\footnotetext{
${ }^{46}$ For Scottewatre, see De Situ Albaniae, ed. by Anderson in Kings and Kingship, pp. 240-43.

${ }^{47}$ Bede, $H E, \mathrm{~V}, 23$.

${ }^{48}$ The twelfth-century Historia Norwegie, ed. by I. Ekrem and L. B. Mortensen (Copenhagen, 2003), VI, displays a poor grasp of ninth-century realities when it explains Terra Petorum (Péttland) as the old name of Orkney, the Mare Petlandicum thus separating this country from Scotia.

49 The fact that the Pentland Firth is a strait rather than a fjord, per se, leads one to wonder whether the name was not, perhaps, originally applied to the Moray Firth, which penetrated the heart of the Pictish kingdom. As the water separating Scotland from the earldom of Orkney, its geographical location may have retreated before advancing Scottish frontiers.

50 The use of the ethnonyms Skottar and Irar in skaldic verse would repay reinvestigation. Pettar does not appear in the surviving corpus.
} 
Considering what seemed most natural for a West Saxon writer returns us to the choice of the term Stracledwalas by the annalist(s) writing the text prior to and including the entry for $920 \mathrm{~A}$. MS C does not, of course, include the entry for 920 but does contain that for $875 \mathrm{~A}$ under $876 \mathrm{C}$. Here Strecled Wealas is written as two words rather than as a simple compound. No form of the term 'Strathclyde' appears in any of our Northumbrian sources, Latin or vernacular. The closest they come is in the account in Historia Regum Anglorum which says that at the Battle of Carham (s.a. 1018) the Scots king Mael Coluim was supported by Eugenius Caluus rex Clutinensium. The term used for Eugenius's kingdom, which was probably intended to be Clutiensium from *Clutienses, would seem to derive from the Welsh vernacular term Cludwys which appears in the poem Armes Prydein, which has been variously dated to between the mid-tenth and the mid-eleventh centuries. ${ }^{51}$ Cludwys denotes 'People of the Clyde'. It might be noted that there is no hint of the word ystrad, the first element of Strecledwalas. As noted earlier this form appears to be Welsh in origin, and it is not the only Welsh form in the Chronicle for the later ninth and tenth centuries. Most obviously, perhaps, one's eye is drawn to the name of the Bishop of Ircingafeld who was kidnapped by Vikings at 914A and 915BC. His name is spelled Cameleac in A and Camelgeac $\mathrm{B}$ and $\mathrm{C}$. This name is modern Welsh Cyfeilliog and this same bishop's name is variously spelled in the Book of Llandaf (an early twelfth-century text based in part upon a range of somewhat earlier written sources) as Cimeilliauc, Cimelliauc, and Ciueilliauc. ${ }^{52}$ Since the Welsh sound represented in these forms by 'au' had earlier been /a:/ the final syllable causes no problems. Similarly the first vowel would, by the tenth century, have been a schwa, represented in modern orthography by ' $y$ ' and open to a number of interpretations in Old English. More problematic is the medial ' $\mathrm{m}$ '. Original British $/ \mathrm{m} /$ had by the eleventh century, at the latest, lenited or spirantized to become $/ \mathrm{v} /$. One methodology for assessing the date of the change might have been conventions adopted to represent these elements in Old English. The fact that Old English Defna (the genitive plural form of the people of Devon,

${ }^{51}$ Armes Prydein: The Prophecy of Britain from the Book of Taliesin, ed. by Sir Ifor Williams (English version by R. Bromwich) (Dublin, 1982), line 11. Sir Ifor presents the case for a midtenth-century date. For the suggestion of a mid-eleventh-century date, see C. Etchingham, 'North Wales, Ireland and the Isles: The Insular Viking Zone', Peritia, 15 (2001), 154-87 (pp. 183-86).

52 Jackson, Language and History, p. 298. For the date and character of the Book of Llandaf, see J. R. Davies, 'Liber Landavensis: Its Date and the Identity of its Editor', Cambrian Medieval Celtic Studies, 35 (1998), 1-12, and the same author's The Book of Llandaf and the Norman Church in Wales (Woodbridge, 2003). 
823A) derives from an original British stem Dumn- whereas Bede (writing c. 730 of events of the early seventh century), the Tribal Hidage (Elmed sætna), and the modern Yorkshire place-names preserve original British Elmet, whilst in Welsh this became Elfed, might bear this out. ${ }^{53}$ Attempts, however, by Förster and Jackson to tie down the chronology by surveying British place-name elements borrowed into English failed to produce clear results. ${ }^{54}$ In part this was because of the ambiguous evidence regarding Old English reception of the nasalized intermediate forms, and in part due to the philologists' use of historical and archaeological frameworks which are no longer regarded as valid. A further factor may be the failure of either scholar to even consider the possibility that some of these Celtic place-names might, like the words Picti $>$ Peohtas and Scotti $>$ Scottas, have been transmitted to Old English (or its ancestral Germanic dialects) via the medium of Romance, in which $/ \mathrm{m} /$ is unlikely to have undergone lenition. This latter factor may, for example, account for the complete absence of $/ \mathrm{v} /$ forms in the heavily Romanized counties of Dorset, Wiltshire, and Hampshire.

Jackson noted that Cameleac represents an extremely late reception of $/ \mathrm{m} /$, or even an $/ \mathrm{m} /$-like nasal form, but presuming a reliance on oral transmission was forced to accept that this was what it was. He even pointed to another name in the same Chronicle entry, Deomedum (914A, 915BC), to demonstrate that the sound could so be received in this period. ${ }^{55}$ In fact there are three, and possibly four, names derived from Welsh in this entry. The annal begins with an account of the arrival of the Vikings: 'Her on pysum geare com micel sciphere hider ofer supan of Lidwiccum. ${ }^{.56}$ The term Lidwicce, 'Bretons', is a borrowing of Old Welsh Litewic. The term Lidwiccium also appears at $885 \mathrm{~A}$ (886B and C, with minor orthographic differences).

The fourth possible Welsh name is a part of that used for the island Flatholm, Bradan Relice. Although bradan is simply Old English for 'broad' or 'flat', relice is hard to explain in Old English terms. According to Caradog of Llancarfan's mid-

\footnotetext{
${ }^{53}$ Bede, HE, II, 14, and for the Tribal Hidage, see David N. Dumville, 'The Tribal Hidage: An Introduction to its Texts and their History', in The Origins of Anglo-Saxon Kingdoms, ed. by Stephen Bassett (London, 1989), pp. 225-30.

${ }^{54}$ M. Förster, 'Keltisches Wortgut im Englischen', in Texte und Forschungen zur englischen Kulturgeschichte, Festgabe für Felix Liebermann, ed. by M. Förster and K. Wildhagen (Halle, 1921), pp. 119-242; Jackson, Language and History, pp. 480-94.

55 Jackson, Language and History, p. 492.

${ }^{56} 914 \mathrm{~A}$ : 'Here in this year a great fleet came hither out of the South from among the Lidwicce.'
} 
twelfth-century Vita Gildae this island was called Ronech in Welsh. ${ }^{57}$ So far as I am aware this name is known only from this single reference and it may be that it represents a related form to Relice. What Jackson did not consider was that the annalist may actually have had some knowledge, albeit imperfect, of written Welsh.

A familiarity with written Welsh might also explain the use at $875 \mathrm{~A}(876 \mathrm{BC})$ and 920A of Stracledwalas. It should be noted that the prosthetic vowel /y/ in modern Welsh ystrad was not indicated in the Old Welsh period. In Welsh sources ystrad written istrat or estrath first appears alongside the more conservative form strat in the Book of Llandaf, compiled between 1119 and 1134. The form estra[t]h appears in David I of Scotland's charter granting Annandale, Estrahanent, to Robert de Brus from $c .1124$, and may thus be the earliest example of the prosthetic $/ y /$ in this word. Morris Jones believed, on the basis of this evidence, that prosthetic/y/ was not present before this period. ${ }^{58}$ The simultaneous appearance of the prosthetic /y/ in Dumfriesshire and Glamorgan should, however, immediately raise our suspicions. While an innovation might emerge at precisely the same moment in two non-contiguous territories the likelihood is against it, particularly as, by the early twelfth century, British may no longer have been spoken in Annandale. It is more likely that what we are observing here is the phenomenon of scribes, trained outwith the Cambro-Latin tradition, writing what they are hearing. Jackson has pointed to a single earlier instance of prosthetic / $y$ / of which Morris Jones seems not to have been aware. ${ }^{59}$ This appears as a feature of the word istlinnit in the ninth-century Juvencus Manuscript which also contains glosses and additional material from the late ninth and early tenth centuries. ${ }^{60}$ Helen McKee has argued that this manuscript began its life in south-east Wales, possibly at a centre such as Llanilltud Fawr or Llancarfan. ${ }^{61}$ She further points to the fact that the author of

${ }^{57}$ Caradog of Llancarfan, Vita Gildae, in Two Lives of Gildas, ed. by Hugh Williams (London, 1899; repr. Felinfach, 1990), pp. 96-97.

${ }^{58}$ J. Morris Jones, A Welsh Grammar: Phonology and Accidence (Oxford, 1913), pp. 26 and 49. For the Annandale charter, see The Charters of David I, ed. by G. W. S. Barrow (Woodbridge, 1999), pp. 61-62.

59 Jackson, Language and History, pp. 527-28.

${ }^{60}$ Cambridge, University Library, MS Ff.4.42 (1285), now published as The Cambridge Juvencus Manuscript Glossed in Latin, Old Welsh and Old Irish, ed. by Helen McKee, 2 vols (Aberystwyth, 2000). Istlinnit appears at fol. $3^{\mathrm{v}}$, line 23 and is in the hand of Scribe B which McKee dates to the later ninth century.

${ }^{61}$ Helen McKee, 'Scribes and Glosses from Dark Age Wales: The Cambridge Juvencus Manuscript', Cambrian Medieval Celtic Studies, 39 (2000), 1-22 (p. 22). 
a Latin cryptogram in the manuscript, which she believes is original to it, identifies himself as Cemelliaucprudens prespiter [sic] (Cyfeilliog, prudent priest). Bearing in mind the geographical and chronological proximity, together with the rareness of the name, she suggests that this scribe may be the same man, at an earlier stage in his career, as the bishop whose capture by Vikings was noted at $914 \mathrm{~A} .{ }^{62}$ If Jackson is correct in his assumption that the presence of the prosthetic/y/, ' $\mathrm{i}$ ', in istlinnit in Juvencus reflects the spoken usage of the ninth century, then it makes it more likely that the absence of the prosthetic /y/ from the Old English Stracledwalas indicates that the term Stræcled derives, ultimately, from a written source.

It would be going too far to suggest that the chronicler (or chroniclers) responsible for these annals was (or were) Welsh, or even that he (or they) had a particular interest in Welsh affairs; there is far too much left unsaid for that. Nonetheless the proposition might hold good that he (or they) were working in a house (or houses) which had established connections with south Wales and were in possession, perhaps, of Cambro-Latin books and familiar with Welsh ecclesiastics. Such circumstances may have contributed in part to the Chronicle's perception of the world beyond Wessex. The presence of Asser of Mynyw at Alfred's court indicates that intellectual exchange between south Wales and Wessex could happen in this period, and the transfer of the early ninth-century Cambro-Latin codex known as 'St Dunstan's Classbook' to Glastonbury, by the early tenth century at the latest, is further evidence of such exchange. ${ }^{63}$

In conclusion, this study of the reporting of 'Scottish' affairs in the AngloSaxon Chronicle, limited as it has been to the Southern Recension, has shed new light upon the transformation of the kingdom of Wessex, with interests and experiences focused in the south-west of the island of Britain, into an English kingdom. The reign of Alfred and much of that of his son Edward, before the annexation of Danish territory began $c .917$, saw the development of a southern hegemony that had little interest or influence in the North Sea world and which incorporated Welsh polities, in Asser's words, 'sicut Æthered cum Merciis' (in like manner to Æthelred with the Mercians). ${ }^{64}$ This relationship with the Britons, which has in the past been underplayed, is particularly interesting. The annexation of the Danish kingdoms, and indeed of English Mercia, which began in Edward's later

\footnotetext{
${ }^{62}$ McKee, 'Scribes and Glosses', p. 21.

${ }^{63}$ For Asser, see Keynes and Lapidge, pp. 48-58. For the codex, see St Dunstan's Classbook from Glastonbury: Codex Biblioth. Bodleianae Oxon. Auct. F. 4.32, ed. by R. W. Hunt, facsimile edn (Amsterdam, 1961).

${ }^{64}$ Asser, Chapter 80.
} 
years and was continued by his sons, transformed the nature of this hegemony. It became more inclusive, with regard to its English components, and more eastward looking, at the expense of its relations with the Britons. This aspect of the formation of English identity has perhaps been underplayed in the past. Our views of early English history tend to be polarized between the age of Bede, when Britons and Saxons were divided by religion (the pagan-Christian dichotomy being replaced by the Paschal controversy), and the age of West Saxon hegemony, when Englishness was consciously cultivated to legitimize political ambitions. AngloBritish relations between the later eighth and the early tenth century may have been more complex, particularly in ecclesiastical and scholarly affairs. To some extent this situation may be reflected in the interests and vocabulary of the Chronicle.

University of St Andrews 
